\title{
The modernisation of the rice value chain in Senegal: A move toward the Asian Quiet Revolution?
}

\author{
Guillaume Soullier ${ }^{1}$ and Paule Moustier ${ }^{2}$
}

\section{Abstract}

The modernisation of domestic food chains in India, Bangladesh, and the People's Republic of China is characterised by technological change and the integration of the collection function by the midstream segment. This has improved product quality and resulted in increased value added for value chain actors. In Africa, since the first world food crisis, governments have endeavoured to develop domestic value chains. The purpose of this paper is to review the dynamics of the rice value chain in Senegal in order to see the extent to which it follows the same trends as in Asia. We have completed the paradigm of Structure-ConductPerformance with the Global Value Chain analysis framework, which highlights the influence that one stakeholder in a steering position can have on the distribution of tasks, skills and margins among the actors in the chain. We conducted 154 qualitative interviews to understand changes in governance. We also used data about 913 stakeholders to assess the competitiveness of the value chain. We found that the Senegalese rice value chain is undergoing modernisation as in Asia. Nevertheless, in Senegal, (1) midstream actors already carried out paddy collection through spot transactions with a trend towards relational governance, (2) credit policies contributed directly to the shift in governance towards integration and (3) the modern rice VC was able to compete cost-wise with imports thanks to state intervention. In order to improve the competitiveness of this value chain, we recommend the inclusion of small-scale processors in the modernisation process through improved access to credit. We also suggest carrying out feasibility studies relating to the use of small-scale mechanisation.

Keywords: Africa, contract farming, governance, policy, rice, Senegal, value chain, vertical co-ordination

${ }^{1}$ CIRAD, UMR ART-DEV, F-34398 Montpellier, France. ART-DEV, Univ Montpellier, CIRAD, CNRS, Univ Montpellier 3, Univ Perpignan, Via Domitia, Montpellier, France. Corresponding author. Email: guillaume.soullier@cirad.fr

${ }^{2}$ CIRAD, UMR MOISA, F-34398 Montpellier, France. MOISA, Univ Montpellier, CIHEAM-IAMM, CIRAD, INRA, Montpellier SupAgro, Montpellier, France.

\section{Acknowledgements}

This paper was funded by AgropolisFondation under reference ID 1403-033 through the 'Investissements d'avenir' program (Labex Agro:ANR-10-LABX-0001-01). This paper also received support from the French Ministry of Research (through Montpellier University) and CIRAD. We thank Bruno Barbier, Matty Demont, Frédéric Lançon, Florence Palpacuer and Thomas Reardon for their comments about previous versions of this paper. 


\section{Introduction}

Agricultural growth plays a major role in poverty reduction and economic development (World Bank, 2008). Research work has highlighted a number of positive impacts of standards and vertical co-ordination on rural livelihoods (see, for example, Swinnen \& Maertens, 2007). However, such work has primarily been documented for global value chains (VCs).

In a context of growing urbanisation and in the wake of the global food price crisis, domestic food chains deserve greater attention. Research conducted by Reardon, Chen, Minten, \& Adriano (2012) revealed the modernisation of the domestic rice and potato VCs in India, Bangladesh, and the People's Republic of China. This modernisation was referred to as the Quiet Revolution. It was characterised by technological change and the integration of the collection function by rice millers and wholesalers, resulting in improved product quality and greater value added for VC actors.

There is a need for research into the transformations of African domestic food chains. Certain research conducted in the 1990s highlighted the situation in traditional VCs. These VCs were characterised by a high number of intermediaries using little capital and handling limited volumes of products that were of heterogeneous quality. Nevertheless, evidence of the transformation of domestic VCs since the 1990s remains limited (Soullier, 2017). Such research should be carried out because policies aimed at modernising domestic rice chains have recently been recommended by international organisations (CARD, 2008; World Bank, 2008) and implemented in several African countries. These recommendations focus in particular on rice, which is a major staple in West Africa (Mendez del Villar \& Lançon, 2015). The priority of these policies is to increase the production of agricultural goods through intensification and, to a much lesser extent, to develop processing capacities (Demont, 2013).

Some works have recently begun documenting the transformation of domestic food chains in Africa (Reardon et al., 2015). They show that the supermarket revolution is not going on (Tschirley, Ayieko, Hichaambwa, Goeb, \& Loescher, 2010), with a few notable exceptions such as Kenya (Neven \& Reardon, 2004). Evidence of the transformation of African domestic chains relates more to actors carrying out processing, storing and wholesaling functions (Reardon et al., 2013). Some works have reported large-scale investments in processing facilities and/or contract farming. These have been observed in the maize VCs in Ghana (Ragasa, Lambrecht, \& Kufoalor, 2018) and Nigeria (Ofuoku \& Agbamu, 2016), as well as in the rice VCs in Nigeria (Awotide, Fashogbon, \& Awoyemi, 2015), Benin (Maertens \& Vande Velde, 2017) and Ghana (Bidzakin, Fialor, \& Yahaya, 2018). In horticultural food VCs in Rwanda, the emergence of contracts, direct relationships between farmers and retailers and the integration of agricultural production by processors has been observed (Verhofstadt \& Maertens, 2013), while in Tanzania, the food system has begun supplying a wide variety of locally processed, high-quality products which are competitive relative to imports (ljumba, Snyder, Tschirley, \& Reardon, 2015). Nevertheless, such evidence remains scarce (Soullier, 2013). 
In this paper, we study the history of the rice VC in Senegal along with the situation in 2014 because it appears to provide a good case, reflecting what has previously been observed in Asia. The purpose of the paper is to review the dynamics of this rice $V C$ in order to see the extent to which it reflects the technological and organisational transformations described by Reardon et al. (2012). To this end, we have completed the Structure-Conduct-Performance paradigm using the Global Value Chain analysis framework (Gereffi, Humphrey, \& Sturgeon, 2005), which highlights the influence that one stakeholder in a steering position can have on the distribution of tasks, skills and value added within the VC. The performance of the chain is considered in terms of competitiveness, particularly with regard to product quality, the quantity supplied, production costs, stakeholder margins and final prices.

In the following pages, we outline the conceptual framework (section 2) and methodology (section 3). We subsequently analyse the historical change in governance of the Senegalese rice VC (section 4), the modernisation of this VC in 2014 (section 5) and the distribution of costs and margins along the chain (section 6). We then endeavour to determine the extent to which a Quiet Revolution is underway in Senegal by comparing it with the Asian transformation (section 7). Finally, we conclude and present a number of policy implications (section 8).

\section{Conceptual framework}

The conceptual framework analyses the influences of technological change and policies on the governance of the VC. It also links these changes to the competitiveness of the chains, measured in terms of product quality, quantity supplied, production costs, distribution of margins and final prices.

The Quiet Revolution framework is mostly empirical, with reference to the Structure-Conduct-Performance paradigm based on Bain (1959). This paradigm links the structure of markets (degree of concentration and differentiation of firms) to the performance of the sector (reduction of costs and generation of profits). It also analyses the functions performed by the actors in the chain, the technologies they use, and the scale of their activities.

We complete this paradigm with the Global Value Chain theory (Gereffi et al., 2005). This framework analyses the influence that an actor in a steering position has on the distribution of tasks and skills along the chain. This is an important dimension of the Quiet Revolution, documenting how the midstream segment (actors carrying out the functions of processing, storing, and wholesaling) influences the upstream segment (actors carrying out the functions of agricultural production and collection of products). The Global Value Chain framework analyses the global commodity chains, 'a network of labour and production processes whose end result is a finished commodity' (Hopkins \& Wallerstein, 1986, p. 159). A global commodity chain can be characterised by four dimensions: the input-output structure, the territory covered, the type of governance, and the institutional framework. Governance is defined as the 'authority and power relationships that determine how financial, material, and human resources are allocated and flow within a chain' (Gereffi \& 
Korzeniewicz, 1994, p. 97). Three variables, representing the characteristics of the industry and production process, explain the dynamics of VC governance: the complexity of transactions, the ability to codify these transactions, and the capabilities of the supply base. They determine five types of governance. Governance by the market concerns simple spot transactions in which price is the only element of co-ordination. When transactions are complex, but the suppliers are able to meet different forms of demand, this is referred to as modular governance. Relational governance describes transactions, often informal, in which the stakeholders are socially close, exchange information, and may develop personalised relationships, thus reducing uncertainty but also creating a situation of interdependence. Captive governance refers to the strong involvement of a leading firm in the operations of its suppliers. Finally, in hierarchy governance, the body of operations is controlled by the same stakeholder.

Technological change is defined as the use of new production methods. In the case of the Senegalese rice VC, technological change is characterised by a shift in milling equipment. In traditional VCs, small-scale processors mill less than one tonne of paddy per hour with technology performing only the shelling function. Technological change is brought about with investments in semi-industrial technology which mills between one and two tonnes of paddy per hour, and in industrial technology that theoretically mills up to four tonnes of paddy per hour. These two types of technology perform quality-enhancing functions, such as drying, cleaning, and grading.

The Global Value Chain framework highlights how technological change brings about changes in governance, product quality and the distribution of costs and benefits (see Figure 1). Technological change tends to steer governance towards forms of vertical co-ordination when its aim is to improve the quality of the final product by controlling the quality of supplies (Gereffi et al., 2005). For instance, industrial milling technologies require paddy with a precise, uniform humidity rate in order to supply high quality rice. For this reason, industrial millers may define the rice growing conditions through a contract.

The institutional dimension of VCs includes policies that can also influence the dynamics of governance towards spot transactions or vertical integration. Direct interventions in the VC may be implemented by state agencies taking part in transactions. Indirect interventions may constrain the actors of the VC through norms and taxes, and support them with subsidies, technical support and financial devices. These policies may consequently lead to new forms of governance.

Finally, technological change and policies erect barriers to entry that determine the distribution of costs and margins among the stakeholders. Such barriers to entry to the activity arise from quality enhancement, labelling, and integration strategies. The actor implementing the innovation obtains the greatest share of the value added (Kaplinsky, 2000). 
Figure 1: Impacts of technological change on governance

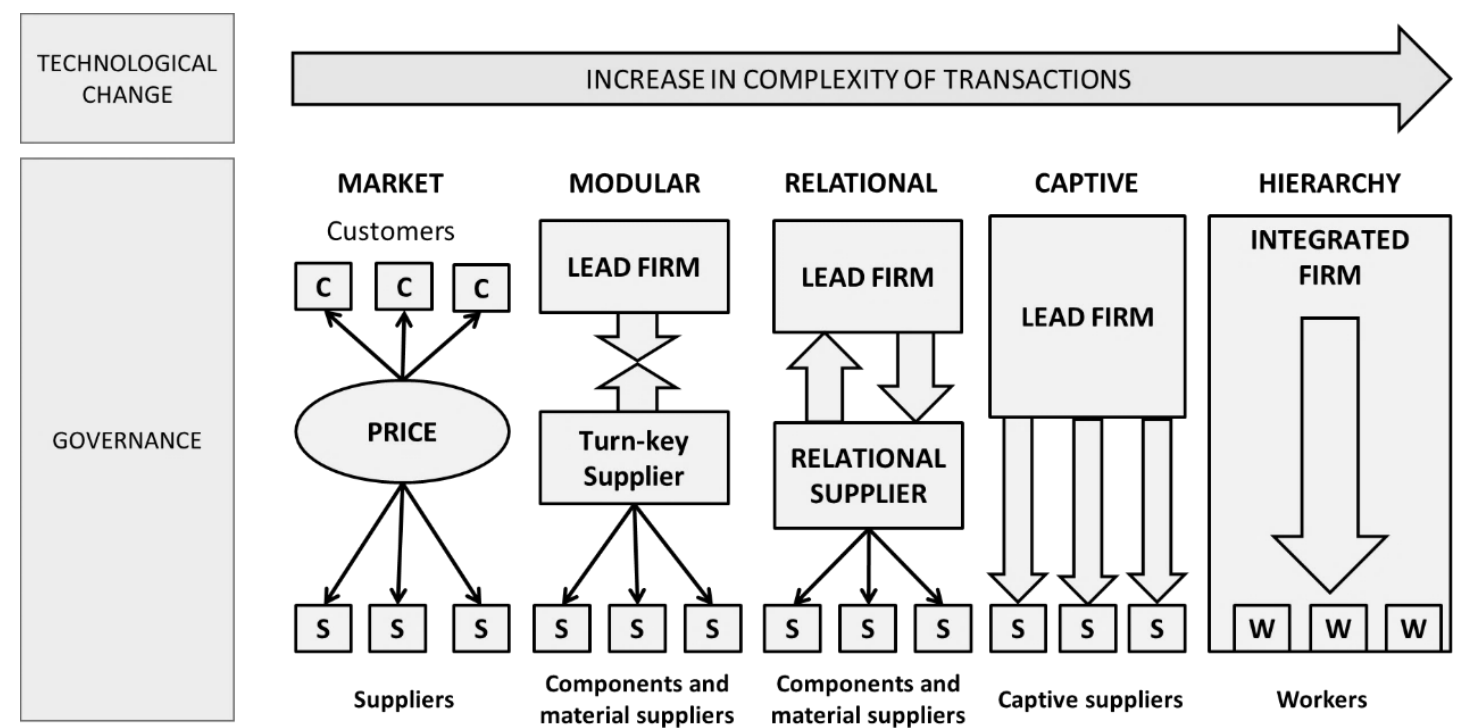

Source: Adapted from Gereffi et al. (2005)

\section{Methodology}

We define the modernisation of domestic food chains as the process of technological change in the midstream segment and the shift in governance towards vertical co-ordination. This process results in improved product quality, as well as an increase in final price and value added. On the contrary, traditional VCs are characterised by a high number of VC actors who use little capital and handle limited volumes of products displaying heterogeneous quality.

We selected the rice VC in Senegal as it seemed to provide a good case reflecting the Quiet Revolution, with investments in modern milling technologies and new co-ordination modes between farmers and processors (Baris \& Gergely, 2012; Demont \& Rizzotto, 2012; Demont et al., 2013). Data collection aimed at better characterising this modernisation. We conducted 154 in-depth interviews, focusing on stakeholders in the upstream and midstream VCs located in Dagana Department, as technological and co-ordination changes mainly occurred at their level. We carried out 47 interviews with farmers and a further 38 with small-scale and industrial rice millers. We also carried out interviews with 23 traders operating in Dagana and Dakar, including wholesalers, importers and retailers, and 46 interviews with agents of public and private research and development organisations. The topics discussed were policies, stakeholder behaviour, quality management, and changes in co-ordination.

We also used quantitative questionnaires to assess the distribution of margins and costs along the chain in 2014. Databases included 550 rice growers randomly selected after stratification according to their marketing 
strategies (Soullier \& Moustier, 2018) 349 rice millers, and 60 rice traders, randomly selected. We also used data from François et al. (2014), who carried out a survey of 254 retailers in 2014 in order to assess net margins along the downstream segment of the same VC. Retailers from Dakar and other major cities in Senegal were randomly selected after stratification per quarter. They were surveyed with regard to their costs and returns and asked to indicate their suppliers, who, in turn, were surveyed.

\section{From State intervention to liberalisation (1960 to 2010)}

Historically, public policies and global markets have hindered or fostered modernisation of the rice VC (Bélières \& Touré, 1999; Fall, 2006).

\subsection{Hierarchy governance driven by the State (1960-87)}

The expansion of irrigated rice growing started in the Senegal River Valley after independence was obtained, in 1960 (Le Gal, 1995). State intervention supported the development of the VC: each segment was directly or indirectly managed through two state agencies, the Société Nationale d'Aménagement et d'Exploitation des Terres du Delta (SAED) and the Caisse de Péréquation et de Stabilisation des Prix. SAED set up the hydroagricultural infrastructure at a rate of 600 ha per year from 1965 to 1980 (Bélières \& Touré, 1999). It also provided farmers with technical advice and subsidised inputs. The intensification of rice cropping started in 1973 (Le Gal, 1995), with land preparation, the use of high-yield and non-mixed varieties, mineral fertilisers, chemical weeding, and mechanised harvesters. Farmers marketed their paddy to two rice mills managed by SAED, which bought it at a fixed price regardless of moisture and impurity content (Fall, 2006). The Caisse de Péréquation et de Stabilisation des Prix was in charge of rice distribution and taxed imports in order to subsidise the purchase of domestic paddy. However, this formal VC became deficit-ridden and collapsed because the rice was sold at prices below processing and purchasing costs, and taxes on imports were not sufficient to cover the deficit.

In parallel to that formal VC, a traditional, informal chain appeared (Bélières \& Touré, 1999). Small-scale processors used mills that only provided the milling function and supplied unsorted rice with impurities (Fall, 2006). They obtained their supplies from farmers, with whom they carried out frequent spot transactions and developed relational proximity. Farmers used this VC to obtain a quick cash return, while it sometimes took several months via SAED. Some farmers also used this VC to sell their paddy without paying off their loans.

${ }^{3}$ The database contained 265 farmers involved in spot transactions, 155 farmers involved in production contracts, and 130 farmers involved in marketing contracts. 
Since co-ordination between stakeholders was state-planned, governance of the rice VC during this period was integrated, and the chain was driven by public bodies. Governance of the emerging informal VC tended to be market-based with a relational component.

\subsection{Liberalisation and market governance (1987-2007)}

State intervention diminished, and the national economy opened up to global markets. The production factor markets (land, credit, seed, and pesticides) were opened to competition in 1987. In particular, land development was turned over to the private sector. This resulted in an increase in irrigated land from 23,000 ha in 1987 to 40,000 ha in 1991 (Bélières \& Touré, 1999). Investments were nevertheless made in low-quality hydro-agricultural equipment in terms of drainage and solidity of bunds, resulting in low output. On the other hand, SAED continued supporting production. A national bank called Caisse Nationale de Crédit Agricole du Sénégal (CNCAS) was created (Fall, 2006). It proposed various loan formats for production, investment, and marketing. In the case of production credit, the bank paid traders who provided inputs to farmers' organisations, who in turn repaid the bank once the paddy was sold. This system increased credits from FCFA 150 million $^{4}$ in 1987 to 5 billion in 1993 (Bélières \& Touré, 1999). Nevertheless, the bank found itself in deficit due to low reimbursement rates and the state paid for this deficit (Fall, 2006). It then hardened its selection criteria. Private financial institutions became also involved in the Senegal River Valley, but they faced the same problem.

It was against this backdrop that the traditional VC developed. In 1994, the rice mills owned by SAED were privatised, prices were deregulated, and the currency (CFA franc) was devalued. The private sector was encouraged to invest through subsidies and development projects. Between 1981 and 1996, processing capacities increased by a factor of 13 and production increased by a factor of 4.5 (Bélières \& Touré, 1999). As a result, in 1996, the Senegal River Valley had the capacity to process 164,000 tonnes of paddy but production reached only 75,000 tonnes. These figures include the development of small-scale processors. From 1994 to 1995, the share of paddy processed by industrial mills decreased from 62\% to $11 \%$, while smallscale processors increased their activity (Bélières \& Touré, 1999). From 1996 onwards, industrial mills became unprofitable because of marketing subsidies being withdrawn, bad harvests, strong competition from small-scale processors, high depreciation costs and a collapse in rice prices due to international competition (Bélières \& Touré, 1999). This led to a concentration of the midstream segment. Some industrial rice millers were nevertheless able to collect paddy thanks to their relational proximity with farmers and their ability to pay them quickly (Bélières \& Touré, 1999).

\footnotetext{
${ }^{4}$ Fixed exchange rate is: 1 euro $=655.957$ FCFA.
} 
The relationship between producers and processors was governed by the market, tending towards relational governance. Local rice was of lower quality than imported rice because small-scale processors did not use moisture meters when purchasing their paddy and used simple milling technologies.

\subsection{A favourable context supporting modernisation since 2007?}

From 2007 on, the context became favourable to the modernisation of the Senegalese rice VC. First, the global food price crisis started in 2007. Thai rice prices (A1 grade) increased from USD 270 to USD 516 per tonne between 2007 and 2012, peaking at USD 850 in May 2008 (Osiriz, 2017). That was an incentive to invest in domestic rice production and processing technologies.

Second, following that price crisis, the inter-ministerial council set up a national programme for rice selfsufficiency (MA, 2009). It aimed to expand land capacities and increase loan for production, processing, and marketing. CNCAS, SAED, and USAID helped farmers and processors to co-ordinate their activities more effectively in order to make higher quality rice available by setting up marketing contracts. Furthermore, AfricaRice worked at improving the seed used by farmers, and the Japanese International Co-operation (JICA) set up projects to improve processing technologies, secure processor supplies, and promote local rice. Finally, the Millennium Challenge Account programme rehabilitated and extended the road network and irrigation infrastructures in 2010 (Embassy of the United States of America, 2010).

Third, it was demonstrated by experiments that local rice could compete with imported rice if its quality were adapted to the preferences of consumers in terms of aroma, homogeneity and purity of the grains, branding, and labelling (Demont, 2013; Demont \& Ndour, 2015). Demont and Rizzotto (2012) proposed a three-stage policy sequence for modernising the Senegalese rice VC. The first stage focussed on enhancing rice quality though contracts, the improvement of post-harvest practices, and investments in modern milling technologies. The second stage was an increase in scale, through investments in irrigation infrastructures, productivity enhancement and storage infrastructures, as well as by supporting the working capital of the millers. The third stage involved advertising to accelerate the transformation of consumer preferences towards domestic rice.

In that favourable context, agribusiness started investing in the production and processing of different agricultural products in the Senegal River Valley (Soullier, Moustier, Bourgoin, \& Ba, 2018). Volumes of paddy increased from 200,000 tonnes during the 1990s to 415,000 tonnes in 2014. Beginning in 2010, six local processors used previous profits and sometimes subsidies from development agencies to implement technological change. They invested in technologies with higher milling throughputs. The semi-industrial technology could mill between one and two tonnes of paddy per hour while the industrial technology could mill up to four tonnes of paddy per hour. Both types of machine performed functions such as drying, cleaning, polishing and grading that improved the quality of rice. Two foreign processors also invested in similar technologies. 
In 2014, world prices decreased almost to their pre-crisis level (USD 309 in January), and millers faced marketing difficulties. The state intervened in March 2015 to implement an agreement between importers and rice millers (SAED, 2015b). Importers committed to purchasing $100 \%$ of domestic standard broken rice processed by industrial millers and 30,000 tonnes of domestic whole-grain rice. Small-scale processors were not included in this agreement.

\section{Modernisation of the VC (2010 - 2014)}

\subsection{The Senegalese rice VC in 2014}

The Senegal River Valley accounted for 80\% of national rice production in 2014 (USDA, 2015), the remainder being produced in Casamance. Some 60,000 irrigated hectares were cropped, 54\% of them in dry season (SAED, 2015a). According to the farmers survey, yields averaged $6.6 \mathrm{t} / \mathrm{ha}$ in the dry season and $5.3 \mathrm{t} / \mathrm{ha}$ in the wet season. As a result, 360,000 tonnes of paddy were produced in the Senegal River Valley in 2014. Most of it came from small-scale farmers, whose number was around 45,000 in 2008 (Gergely \& Baris, 2009). Some $86.5 \%$ of these farmers grew Sahel 108 , which is an ordinary variety. Furthermore, $64.63 \%$ of farmer organisations collected one only variety, and the others separated varieties into batches.

In 2014, eight industrial and semi-industrial rice millers each processed between 2,000 and 13,000 tonnes of paddy, making a total of 45,000 tonnes. These figures represented between $38 \%$ and $75 \%$ of their individual milling capacity. The volumes of paddy milled were constrained by the volumes of paddy that rice millers were able to purchase. The rice they supplied was high quality with a low impurity content. Whole grain rice and broken rice were separated.

On the other hand, there were 420 small-scale processors that milled $87 \%$ of the paddy in 2014 . They processed on average 750 tonnes of paddy each. They purchased the same paddy as industrial rice millers and processed it with technologies restricted to the milling function. As a result, they only marketed broken rice that could contain impurities. Medium and large-scale millers stated milling rates averaging $66 \%$, while small-scale processors reported milling rates under $65 \%$.

The rural population in the valley totalled 500,954 people (ANSD, 2015) and the per capita rice consumption in Senegal was $95 \mathrm{~kg} /$ year (Fofana, Goundan, \& Magne Domgho, 2014). As a result, the valley supplied 187,000 tonnes of rice to the rest of Senegal. In 2014 , the national production of 271,750 tonnes of rice was rounded out by 1,053,000 tonnes of imported broken rice, mainly from India (598,000 tonnes), Thailand (197,000 tonnes), and Brazil (52,000 tonnes). Senegal therefore covered around $20 \%$ of national consumption. Whole-grain rice represented $2 \%$ of rice consumption (Hathie \& Ndiaye, 2015), and imports of such rice reached 10,000 tonnes.

In March 2015, following the fall in the global price of rice, the government intervened and importers committed to purchasing the rice from the Senegal River Valley processed by industrial and semi-industrial 
millers (SAED, 2015b). Importers therefore sold domestic and imported rice to wholesalers and semiwholesalers. A total of 15,000 small boutiques, kiosks, and traditional open-air markets (USDA, 2013) sold almost $95 \%$ of the volume of rice (Gergely \& Baris, 2009), while between 1,000 and 1,500 modern retailers sold the remainder. These were convenience stores, and a few supermarkets.

The trade flows within the rice VC in Senegal in 2014 are summarised in Figure 2.

Figure 2: Trade flows within the rice VC in Senegal in 2014

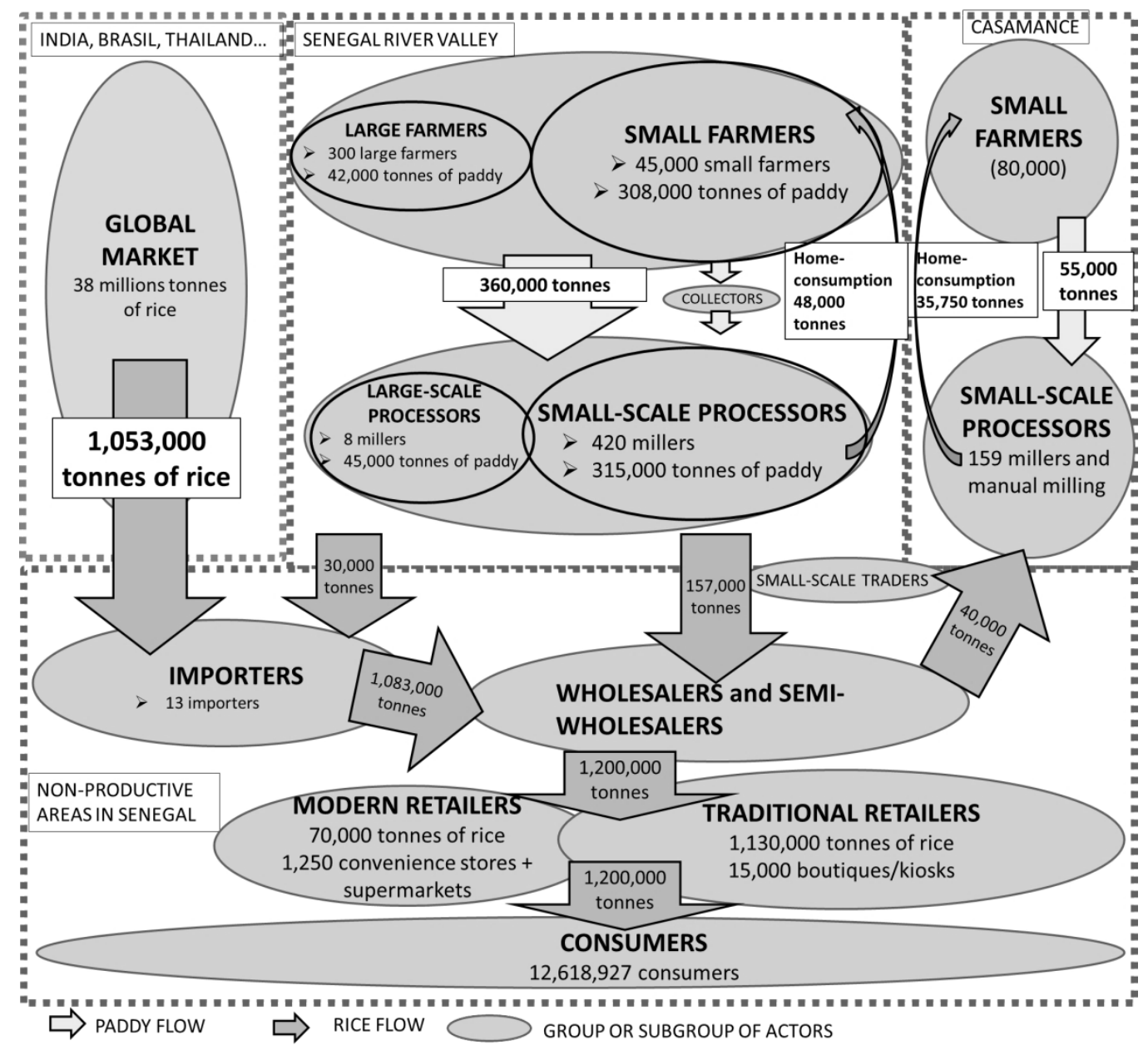

Source: The authors

\subsection{Governance tending towards integration}

The governance implemented by rice millers and farmers was a major issue for upscaling modernisation (Demont \& Rizzotto, 2012). In 2010, there were neither marketing nor formal production contracts. New coordination modes were then adopted to secure the supplies of industrial and semi-industrial rice millers. In 2014, production and marketing contracts each accounted for $5 \%$ of the volumes produced in the Senegal River Valley, while vertical integration accounted for $2 \%$ and farmer networks $1 \%$. Millers and farmers sometimes combined these types of governance. Figure 3 summarises the co-ordination modes. 
Figure 3: Governance modes implemented by farmers and processors within the rice VC in Senegal

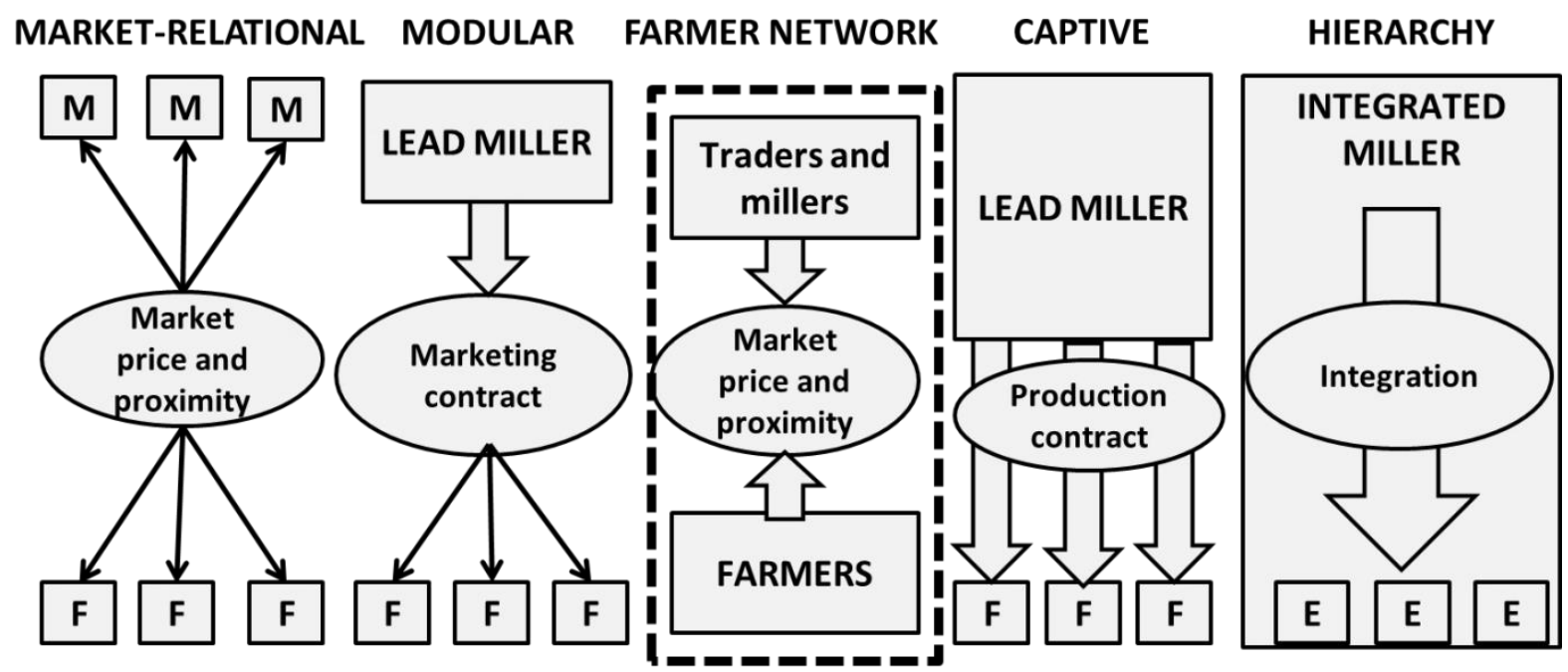

F: Farmers; E: Employees; M: Millers

Source: Adapted from Gereffi et al. (2005)

\subsubsection{The marketing contract: modular governance}

Marketing contracts were set up and increasingly promoted by CNCAS and SAED, with support from USAID. CNCAS informed millers which farmer organisations had taken out a loan. The contract price took into consideration the indicative price negotiated within the inter-professional organisation, the moisture content, the consistency of varieties, and the level of impurities. The average selling price through marketing contracts in the 2014 dry season was 126 FCFA per kilogram. There was no premium since the purchasing price through spot transactions was 124.5 FCFA $/ \mathrm{kg}$. In 2014, marketing contracts were used by 98 farmer organisations growing rice on land covering approximately 4000 ha and including around 2000 small-scale farmers. All of them had access to credit at CNCAS. A total of 15,000 tonnes of paddy was purchased through marketing contracts in 2014. Payment was made directly by millers into the bank accounts of the farmer organisations, from which the loan reimbursement was withdrawn. Millers sold the rice by grade and sometimes aroma, and a brand marker enabled the consumer to identify which firm did the milling.

\subsubsection{Farmer networks: relational governance driven by farmers}

Farmer networks (highlighted by the dotted line in Figure 3 ) involved semi-industrial mills owned by farmers and farmer associations linking farmers and traders. These networks were set up after liberalisation by SAED, development agencies, and non-government organisations. In 2014, around four hundred farmers were members of these networks, which sometimes also managed a credit union. Purchasers of paddy were also from the same network. Networks that did not own their own mill outsourced the milling. Co-ordination 
between farmers, traders, and milling service providers was organised through the network. Stakeholders reported that there were fewer and fewer farmer networks because they were not profitable.

\subsubsection{The production contract: captive governance with some relational aspects}

Production contracts were set up by rice millers. They were drafted with a pre-financing of the inputs. Farmers were financed by millers through credits in cash or in kind. In the latter case, the millers supplied farmers with seed, fertilisers, and sometimes mechanised services. If the farmer did not reimburse the loan, this was generally followed by new negotiations with the rice miller. The contract would include a definition of quality based on moisture and impurity content. The rice was sorted by grade, and a brand enabled consumers to identify the rice miller. Millers might also provide agricultural advisory services. In 2014, production contracts were used by 71 farmer organisations totalling 1,500 farmers growing rice on 3500 ha. Some 15,000 tonnes of paddy were purchased through these contracts. The average purchasing price during the dry season was 104 FCFA per kilogram. Rice millers explained the lower price relative to spot transactions (124.5 FCFA $/ \mathrm{kg}$ ) by a higher risk of non-reimbursement from these contracted farmers (Soullier \& Moustier, 2018). Indeed, $87.1 \%$ of farmers who used a production contract during the 2014 dry season had previously been refused credit from the national bank because of non-reimbursement. Furthermore, $86.6 \%$ of farmers interviewed who signed a production contract stated it was their only means of obtaining credit.

\subsubsection{Vertical integration: hierarchical governance}

There were four vertically integrated mills in 2014 which cropped between 20 and 800 hectares. Three of these mills introduced technological change thanks to support from development agencies. They obtained access to the land through the local council or rented it from farmers and hired seasonal and daily workers. Around 8000 tonnes of paddy processed by industrial millers in 2014 were self-produced. A label with a brand enabled the company to be identified.

\section{Increase in total net margin}

Taking prices of imported broken rice into account, we compare the distribution of costs and margins in 2014. The traditional VC supplied low quality rice, defined as rice containing a heterogeneous mix of whole and broken grains, impurities and different humidity rates. The 'riz de la vallée' brand used in this traditional VC did not make it possible to identify the miller. On the contrary, the modern VC supplied high-quality rice defined as rice with a uniform grain size, easy to cook and with a low rate of impurities. Consumers could identify the miller through the brand. The four modes of vertically integrated co-ordination (marketing contract, farmer network, production contract and vertical integration) were implemented within this modern VC. 
In 2014 , the share of total net margin in the final retail price of broken rice totalled $35.4 \%$ for the traditional VC and $35 \%$ for the modern VC (Table 1). In the case of whole-grain rice, the share of the total net margin was $43.9 \%$.

Table 1: Distribution of margin (FCFA/ $\mathrm{kg}$ ) per category of rice quality in the domestic rice VC in Senegal in 2014

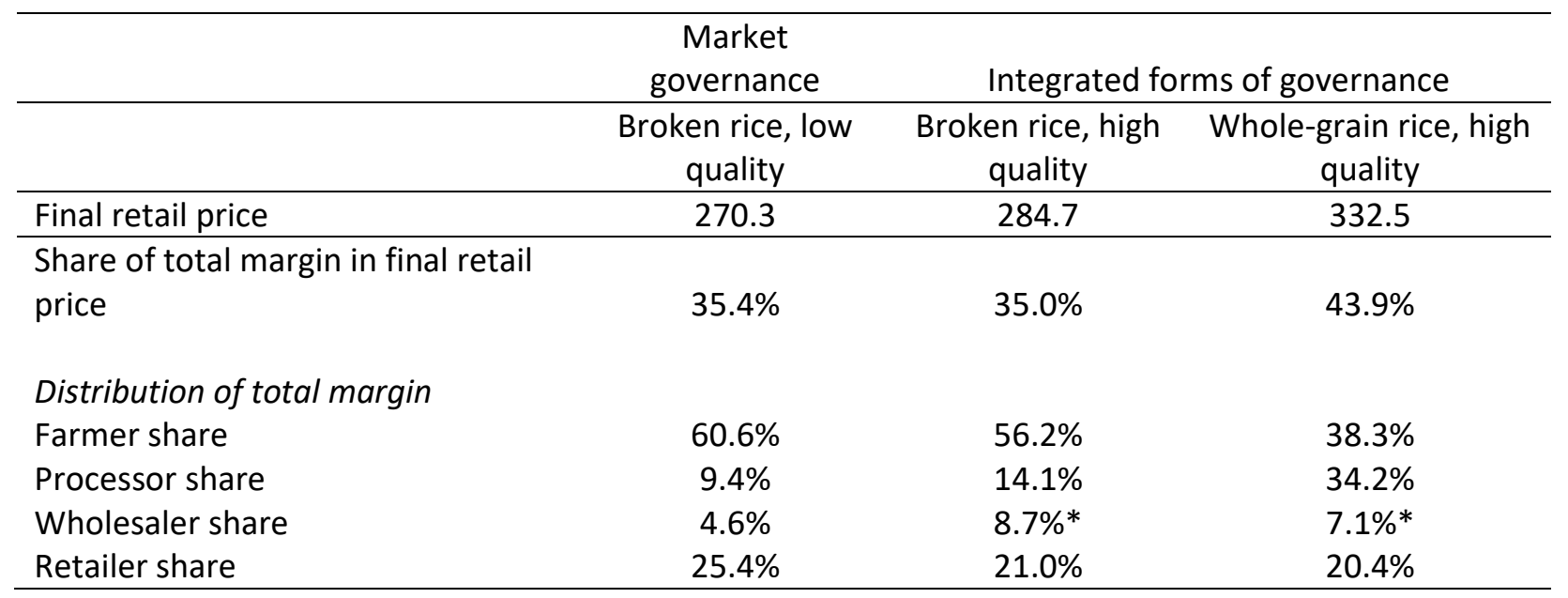

Source: The authors

The margin is calculated as the difference between the total income from sales and the production costs (including capital depreciation), divided by the quantity of rice.

* This figure includes the margin of importers, who participated in the modern VC 
Table 2: Distribution of costs and margin (FCFA/kg) per category of rice quality and actors in the domestic rice VC in Senegal in 2014

\begin{tabular}{|c|c|c|c|c|c|c|}
\hline & \multirow{2}{*}{\multicolumn{2}{|c|}{$\begin{array}{l}\text { Market governance } \\
\text { Broken rice, low } \\
\text { quality }\end{array}$}} & \multicolumn{4}{|c|}{ Integrated forms of governance } \\
\hline & & & \multicolumn{2}{|c|}{$\begin{array}{l}\text { Broken rice, high } \\
\text { quality }\end{array}$} & \multicolumn{2}{|c|}{$\begin{array}{l}\text { Whole-grain rice, } \\
\text { high quality }\end{array}$} \\
\hline & Mean & S.D. & Mean & S.D. & Mean & S.D. \\
\hline \multicolumn{7}{|l|}{ FARMERS } \\
\hline \multicolumn{7}{|l|}{ Farmers cost, per kg of rice } \\
\hline Land preparation & 20.2 & 5.11 & 19.4 & 2.91 & 19.4 & 2.91 \\
\hline Seeds and chemicals & 35.7 & 7.32 & 34.3 & 6.48 & 34.3 & 6.48 \\
\hline Irrigation & 20.3 & 7.99 & 19.5 & 5.26 & 19.5 & 5.26 \\
\hline Harvest and threshing & 37 & 15.23 & 35.6 & 10.01 & 35.6 & 10.01 \\
\hline Other production costs & 17.8 & 10.07 & 17.2 & 7.94 & 17.2 & 7.94 \\
\hline Total, farmer cost & 131 & 46.9 & 126 & 29.58 & 126 & 29.58 \\
\hline Price paid to farmer, per $\mathrm{kg}$ of rice & 189 & 17.4 & 182 & 23.17 & 182 & 23.17 \\
\hline Farmer margin, per kg of rice & 58 & 2.46 & 56 & 2.76 & 56 & 2.76 \\
\hline \multicolumn{7}{|l|}{ MILLERS } \\
\hline \multicolumn{7}{|l|}{ Millers costs, per kg of rice } \\
\hline Price paid to farmer, per kg of rice & 189 & 17.4 & 182 & 23.17 & 182 & 23.17 \\
\hline $\begin{array}{l}\text { Capital depreciation, maintenance and } \\
\text { repairs }\end{array}$ & 5 & 2.5 & 16.6 & 14.4 & 16.6 & 14.4 \\
\hline Energy & 11.1 & 8.16 & 7.2 & 2.09 & 7.2 & 2.09 \\
\hline Manpower & 6.2 & 4.42 & 6.7 & 4.5 & 6.7 & 4.5 \\
\hline Others processing costs & 2.7 & 1.15 & 5.5 & 12.94 & 5.5 & 12.94 \\
\hline Total, miller cost, per $\mathrm{kg}$ of rice & 214 & 19.81 & 218 & 25.17 & 218 & 25.18 \\
\hline Price paid to miller, per kg of rice & 223 & 8.74 & 233 & 15.27 & 263 & 25.16 \\
\hline Miller margin, per kg of rice & 9 & 8.04 & 15 & 13.9 & 45 & 37.22 \\
\hline \multicolumn{7}{|l|}{ IMPORTERS } \\
\hline Importers costs, per kg of rice $*$ & & & 2 & 2.98 & 2 & 2.98 \\
\hline Importer margin, per kg of rice * & & & 5.4 & 2.05 & 6 & 2.05 \\
\hline \multicolumn{7}{|l|}{ WHOLESALERS } \\
\hline Wholesalers costs, per kg of rice & 1 & 0.54 & 1.5 & 3.23 & 1.9 & 3.23 \\
\hline Wholesaler margin, per kg of rice & 4.4 & 0.35 & 8.7 & 0.67 & 10.3 & 0.98 \\
\hline \multicolumn{7}{|l|}{ RETAILERS } \\
\hline Retailers costs, per kg of rice & 17.7 & 1.84 & 14.2 & 2.4 & 14.4 & 2.4 \\
\hline Retailer margin, per kg of rice & 24.3 & 3.54 & 20.9 & 2.25 & 29.8 & 1.04 \\
\hline Final retail price, per kg of rice & 270.3 & & 284.7 & & 332.5 & \\
\hline Total costs, per kg of rice & 174.7 & & 179.7 & & 180.3 & \\
\hline Retail price, less costs, per kg of rice & 95.6 & & 105 & & 152.2 & \\
\hline
\end{tabular}

Source: The authors; The margin is calculated as the difference between the total income from sales and the production costs (including capital depreciation), divided by the quantity of rice.

The costs of importers, wholesalers and retailers do not include rice purchasing.

* Importers who participated in the modern VC 
At production level, the opportunity cost of a production factor for which there is no local market is its production cost. The opportunity cost of a production factor for which there is a local market is its potential market price during the period considered (Boussard, 1987). The opportunity cost of land rental is FCFA 40,000 per hectare. That of manpower is FCFA 500 per day during the whole season except for harvest, when the cost is FCFA 1,500 per day. Transportation of seed, fertilisers, and herbicides cost zero but transportation of paddy costs FCFA 50 per bag of 80 kilogram. Seasonal workers are usually provided with board, which costs FCFA 5,000 per month. Some workers and the use of a threshing machine are often paid in paddy, in the field, during the harvest period. The opportunity cost is FCFA 75 per kilogram. This value is important since in-kind payment of threshing generally represents around $10 \%$ of production costs.

The milling rate is $65 \%$ for the traditional VC and $66 \%$ for the industrial one. Costs for importers, wholesalers, and retailers include transportation, manpower, storage, and credit. In the case of semi-wholesalers and retailers, storage costs were calculated on the basis of the space dedicated to rice.

Farmers did not have premium and higher margin when selling to industrial millers because they supplied paddy of similar quality to the one sold to small-scale processors (Soullier \& Moustier, 2018). The main determinants of their production costs were harvest, threshing, seed and fertilisers.

The margin of industrial millers was slightly higher with high quality broken rice (15FCFA/kg) than the one of small-scale processors (9FCFA $/ \mathrm{kg}$ ). The margin of industrial millers increased with high quality whole-grain rice (45FCFA $/ \mathrm{kg}$ ). Nevertheless, due to different technological and organisational conditions, particularly the volumes of paddy that millers were able to collect, standard deviations of their margins were high (Table 2). Furthermore, these higher margins hide the fact that in 2014, millers faced competition from imported rice and were unable to market their rice without government intervention. The purchasing price of imported broken rice in 2014 was FCFA 225.6 per kg at importer level. The traditional VC was able to compete, as smallscale processors sold broken rice to traders at an average of FCFA 223 per kg. Modern millers, however, were not cost-competitive with imports prior to state intervention because they provided broken rice of a quality similar to the imported one at a higher price (FCFA 232 per $\mathrm{kg}$ ). That is why the state required importers to purchase domestic rice from modern mills (SAED, 2015b). Millers negotiated a marketing price that enabled them to achieve high margins. Importers accepted this agreement because it represented small volumes of domestic rice, and they could continue importing high volumes of rice on which they obtained a margin. The final retail price of broken rice was higher for the modern VC $(284.7 F C F A / k g)$ than the traditional one $(270.3 F C F A / k g)$, and whole-grain was more expensive $(332.5 F C F A / k g)$ than either of them. The price of ordinary broken imported rice ranged from 260 to 275 FCFA/kg in 2014, while the price of imported fragrant whole-grain rice ranged from 300 to 350 FCFA/kg (François et al., 2014; Hathie \& Ndiaye, 2015).

As a result, the traditional domestic VC was able to compete cost-wise with imports of broken rice in 2014, although it supplied rice of lower quality. In contrast, the modern VC was not able to compete cost-wise with 
imports, although providing a similar degree of quality. Large-scale processors stayed in business thanks to state intervention.

\section{Discussion: a Senegalese Quiet Revolution?}

In this section, we discuss the similarities and differences between Asian and Senegalese modernisations (see Figure 4 for a summary). Similarities include certain aspects of policies and demand that favoured the modernisation, the changes in technology and coordination, and the performance of VCs.

On both continents, policies have favoured modernisation through investment in infrastructures (particularly irrigation canals and roads), research and extension and, at times, subsidises for investments in processing technologies and improved inputs. In Asia, the green revolution had enabled farmers to intensify their practices and to increase both yields and the share of produce sold (Reardon et al., 2012). Producers in the Senegal River Valley also intensified agricultural practices from as early as 1973 (Le Gal, 1995). Furthermore, in both case studies, part of the demand was shifting towards higher-quality products.

In both cases, the midstream segments have recently introduced technological changes. In Asia, there has been an expansion in the volume of activity, followed by investments in new technologies in the midstream segment and the concentration of this segment (Reardon et al., 2012). In Senegal, there is also an increasing number of rice millers using upgraded technologies.

Furthermore, there was an 'emerging vertical integration/co-ordination' in the Asian case (Reardon et al., 2014 , p. 11) and we observed the same pattern of governance in Senegal. In Asia, rice millers and potato wholesalers integrated the activity of collecting products. The tied credit-output relationships applied by traditional collectors and farmers disappeared, giving way to vertical co-ordination between millers and farmers or wholesalers and farmers (Reardon et al., 2012). In Senegal, we have also documented the development of contract farming and vertical integration by millers. These millers define new quality criteria for paddy in order to supply rice that is clean, white and with few broken grains. In Asia, millers marketed rice in bags of evenly sized and shaped grains. They also developed branding strategies ensuring traceability for consumers (Minten, Reardon, \& Sutradhar, 2010). Similar strategies were observed in Senegal.

Finally, the performance of VCs changed in a similar way. In Asia, the share in the final amount of the profit margin increased while costs decreased. Changing to quality rice proved advantageous for millers and retailers. For instance, they received $44 \%$ and $49 \%$ respectively of the fine rice quality premium in Bangladesh (Minten, Murshid, \& Reardon, 2013). We also observed an increase in millers' margins in Senegal. In contrast, farmers do not benefit from higher retail prices (Soullier \& Moustier, 2018), a fact which was also documented in Asia by Minten et al. (2013).

In Asia, the modernisation process was most advanced in the People's Republic of China, where modern VCs were predominant. In India, modern VCs expanded quickly, although collectors continued to ply their trade. 
Modernisation was less advanced in Bangladesh, where traditional VCs were predominant, although modernisation was emerging (Reardon et al., 2012). The modernisation of the VC in Senegal is in its infancy and still expanding, similar to the situation observed in Bangladesh (Reardon et al., 2012). Indeed, the modern domestic VC supplies $2.6 \%$ of national consumption.

The modernisations in the Asian countries selected and in Senegal are different in terms of benchmark situations, drivers of vertical coordination and conditions of competitiveness.

First, the benchmark situation is different between the Asian and Senegalese cases. The benchmark situation of the Quiet Revolution was a traditional VC consisting of numerous intermediaries using weakly-capitalised technologies and yielding low-quality products. Farmers bought few inputs, were poorly integrated into markets and were engaged in 'exploitative relationships of tied credit-output linkages where traders lend to farmers and thus underpay and exploit them' (Reardon et al., 2012, based on Lele, 1971). Thanks to infrastructure improvements and income from non-agricultural activities, farmers have been able to fund agriculture and tied credit-output transactions have disappeared. In Senegal, the State had used credit to support production since 1960 through the distribution of inputs by SAED and credit managed by the national bank. Consequently, tied credit-output transactions were much less common than in Asia, and farmers marketed their paddy through spot transactions with a trend towards relational governance (Fall, 2006). Furthermore, the number of intermediaries in Asia has decreased, with the collection function being taken on by midstream stakeholders (Reardon et al., 2012), whereas collection was already undertaken by processors in Senegal.

Second, credit policies in Senegal contributed directly to the shift in governance towards integration. Marketing contracts have been introduced by SAED and the national bank to respond to millers' needs concerning the quantity and quality of paddy and to guarantee reimbursement to CNCAS. Most farmers who use a production contract are refused credit from this national bank because of non-reimbursement of previous credit. They accept production contracts that are less remunerative than other transactions because it is their sole means of obtaining a credit (Soullier \& Moustier, 2018). The main difference between both arrangements is that production contracts are drafted and transactions are complex in terms of paddy quality.

Third, the modern rice VC in Senegal was only able to compete cost-wise with imports thanks to state intervention. Broken rice is a by-product sold at low prices on global markets. In Senegal, modern millers collect limited quantities of paddy because they do not pay a premium (Soullier \& Moustier, 2018). As a result, the quantity of paddy processed by industrial rice millers is linked to the credits obtained by farmers through marketing contracts and production contracts. This generates high capital depreciation costs per kilogram and stifles the competitiveness of the modern rice VC relative to imports. The Senegalese government require importers to purchase domestic rice from modern mills (SAED, 2015b). As a result, largescale processors stay in business and obtain a high share of the margin thanks to state intervention. 
A fourth difference might concern the retail segment. In Asia, downstream transformations tended to move towards the Supermarket Revolution, with investments in modern retailing. In contrast, the Supermarket Revolution does not seem to have started in Senegal, with limited modern retailing outlets (Hathie \& Ndiaye, 2015) and the predominance of traditional shops (François et al., 2014). 
Figure 4: Comparison of modernisation between selected Asian countries (Bangladesh, India, People's Republic of China) and Senegal

\begin{tabular}{|c|c|c|c|}
\hline & & $\begin{array}{c}\text { Selected Asian countries (Reardon et } \\
\text { al., 2012) }\end{array}$ & Senegal (our data) \\
\hline \multirow[b]{2}{*}{ Institutional environment } & Link to global market & Supplier or independent & $\begin{array}{l}\text { Purchaser, competition from global } \\
\text { markets }\end{array}$ \\
\hline & Policies & $\begin{array}{c}\text { Support for modernisation: } \\
\text { infrastructures, research and } \\
\text { extension }\end{array}$ & $\begin{array}{c}\text { Support for modernisation: } \\
\text { infrastructures, research and extension, } \\
\text { credit }\end{array}$ \\
\hline \multirow{6}{*}{ Organisation of the chain } & Production & \multicolumn{2}{|r|}{ Increase } \\
\hline & Processing & $\begin{array}{l}\text { Technological change and } \\
\text { concentration }\end{array}$ & Technological change and expansion \\
\hline & Retailing & Supermarket Revolution & Traditional retailing dominates \\
\hline & Geographical distance & \multicolumn{2}{|c|}{ Increasing } \\
\hline & Number of intermediaries & Decreasing, integration of collection & $\begin{array}{c}\text { Direct relationships between farmers } \\
\text { and processors existed before } \\
\text { modernisation }\end{array}$ \\
\hline & Governance & $\begin{array}{l}\text { From interlinked transactions to } \\
\text { vertical co-ordination; } \\
\text { midstream segment becomes the } \\
\text { driver }\end{array}$ & $\begin{array}{l}\text { From market governance to vertical co- } \\
\text { ordination. } \\
\text { Midstream segment becomes the driver } \\
\text { with policy support }\end{array}$ \\
\hline \multirow{4}{*}{ Performance } & Volumes & $\begin{array}{l}\text { Modern VCs dominate in People's } \\
\text { Republic of China and India and are } \\
\text { emerging in Bangladesh }\end{array}$ & Modern VC is emerging \\
\hline & Quality & \multicolumn{2}{|c|}{ Increase in quality } \\
\hline & Margins & \multicolumn{2}{|c|}{ Increase in total net margin and share obtained by the midstream segment } \\
\hline & Final price & $\begin{array}{l}\text { The modern VC is competitive with } \\
\text { imports. India is a major exporter. }\end{array}$ & $\begin{array}{l}\text { The modern VC is competitive with } \\
\text { imports thanks to State intervention }\end{array}$ \\
\hline
\end{tabular}

Source: Reardon et al. (2012) and the authors 


\section{Conclusions and policy recommendations}

Research conducted by Reardon et al. (2012) revealed the modernisation of the domestic rice and potato VCs in India, Bangladesh, and the People's Republic of China. This modernisation is characterised by technological change and the integration of the collection function by the midstream segment. This has improved product quality and has resulted in increased value added for VC actors.

Certain African countries have adopted policies aimed at modernising domestic food chains, but there is still little evidence making it possible to determine if the same modernisation process is under way in Africa. We have investigated the extent to which the rice VC in Senegal presents the same features of modernisation as the Quiet Revolution. We have completed the Structure-Conduct-Performance paradigm with the Global Value Chain analysis framework (Gereffi et al., 2005), which highlights the influence that one stakeholder in a steering position can have on the distribution of tasks and skills. The dynamics of governance have been analysed from a historical point of view, based on previous research and 154 in-depth qualitative interviews. Calling on quantitative surveys with 913 VC actors, we have also analysed the competitiveness of the VC, in terms of product quality, quantity supplied, production costs, margins and final prices. Some data used by Soullier and Moustier (2018) to evaluate the impacts of marketing and production contracts on farmers' income and food security have been used in this paper to highlight the differences in performance between the modern and traditional VCs.

Public policies and links to the global markets have influenced the governance of the VC since 1960. The rice VC was set up by the government, with intervention in industrial processing and wholesale trade. During the 1990s, the privatisation of the VCs and increased openness to global markets was favourable to the development of small-scale processors, functioning at lower costs. Recently, the increase in prices on the global market, the demand for quality produce (Demont \& Ndour, 2015) and policies aimed at increasing the quantity and quality of rice supplied by the domestic chain have been conducive to the modernisation of the VC.

Processors, sometimes with the support of policies, have set up new modes of co-ordination and implemented technological change. Governance is tending towards integration as there has been an increase in the share of paddy marketed through vertical co-ordination. We have therefore found that the rice VC is undergoing modernisation as described by Reardon et al. (2012). Nevertheless, in Senegal, (1) midstream actors already carried out paddy collection through spot transactions with a trend towards relational governance, (2) credit policies contributed directly to the shift in governance towards integration and (3) the modern rice VC was able to compete cost-wise with imports thanks to state intervention.

The main stages of the policy sequencing recommended by Demont and Rizzotto (2012) to modernise the Senegalese VC have been implemented. Nevertheless, the modernisation process faces difficulties in moving from the stage of quality improvement to that of an increase in quantity. Indeed, the quantity of paddy processed by industrial rice millers is linked to the quantities of paddy used by farmers to reimburse the 
credits within the framework of marketing contracts and production contracts. Rice millers who planned to vertically integrate rice farming also face constraints such as land access or high land development costs. This generates high capital depreciation costs per kilogram and impedes the competitiveness of the modern rice VC relative to imports. Furthermore, although some research has demonstrated that consumers are willing to pay for domestic broken rice of a higher quality, there is still some uncertainty about the size of this segment. The fact that it could be thin could provide another explanation for millers' marketing difficulties. In order to improve the competitiveness of the modern domestic VC with imports, we first recommend the inclusion of small-scale processors in the modernisation process through the promotion of semi-industrial technologies and increased accessibility of operating and equipment loans. Small-scale processors operate at a low cost because they use simple technologies. They have a network of suppliers with whom they realise spot transactions with relational proximity. Relational proximity generates trust and reduces the risk of nonpayment (Moustier, 2012). Spot transactions provide flexibility in marketed volumes and enable quick payments. Nevertheless, these small-scale processors face two major constraints. The first is that the technology they use only performs the milling function, which generates low quality rice. The quality of their production could be improved by supporting their access to compact rice mills (Cruz, 1999), which separate the hulling and whitening operations, and may be coupled with manual graders. The use of such technology would also enable small-scale processors to retain flexibility and low operating costs. Nevertheless, the compact rice mills rely on imports of rubber rolls, so national stocks should be established. Furthermore, the cost of compact rice mills is more than FCFA 2 million, which is twice the price of the machine currently used by small-scale processors.

The second constraint faced by small-scale processors is limited cash flow. Small-scale processors might not obtain a bank credit because they cannot provide the guarantees required by the banks. The level of their own cash flow therefore limits the quantity of paddy they mill. Some of them perform custom milling, an arrangement in which they are paid by the owner of the paddy to mill it. In this case, small-scale processors have no incentive to improve the quality of the rice, because the custom milling price is independent of the rice quality. The lack of small-scale processors' access to bank loans is therefore an impediment to both increasing the volume of paddy and improving the quality of the rice.

We therefore firstly recommend policies to support improved access of small-scale processors to bank loans. The availability of equipment loans would allow small-scale processors to be included in the modernisation process by investing in technology to improve the quality of the rice. Opening up operating loans would also strengthen the modernisation process because it would support small-scale processors in collecting higher volumes of paddy through spot transactions with relational proximity. Such recommendations to promote policies including small-scale processors in the modernisation process are similar to those of Waldron et al. (2010), who advocated incremental development in the case of the beef industry in China. 
Second, policies in Senegal could aim to reduce production costs through small-scale mechanisation. Harvesting and threshing were performed manually in the Senegal River Valley in 2014. This represented $28.25 \%$ of farmers' production costs and $12.5 \%$ and $13.68 \%$ of the final retail price of broken rice from the modern and traditional VCs respectively. The use of mechanised harvesters could reduce these production costs. Nevertheless, policies should carefully consider the issues of collective action and scale of technology. Specific feasibility studies should question the type of small-scale mechanisation that was effective in Asia, and how these machines were managed.

Another issue is that the private interests of rice millers are not always in line with the goal of national selfsufficiency policies. Whole-grain rice in Senegal is a niche segment which is rapidly filled by domestic rice. Since margins are higher for this type of rice, industrial millers try to identify new markets, probably in the region. That rationale runs counter to national policy, but not ECOWAS policy, which relies on a better integrated regional market to ensure food security in West Africa.

The main limits of this research concern the conceptual framework and the orientation of the analysis of the VC in the upper and midstream segments. We mainly used the governance framework whereas the Asian Quiet Revolution was studied using the Structure-Conduct-Performance paradigm. Furthermore, we focused our analysis on relationships between upstream and midstream VC stakeholders. Drivers from the downstream segment of the VC, such as the early stage of a supermarket revolution, could also have influenced the modernisation.

\section{References}

ANSD. (2015). Rapport projection de la population du Sénégal (No. Edition 2015; p. 157). Retrieved from Agence Nationale de Statistique et de la Démographie website: http://www.ansd.sn/

Awotide, B. A., Fashogbon, A., \& Awoyemi, T. T. (2015). Impact of agro-industrial development strategies on smallholder rice farmers' productivity, income and poverty: the case of contract farming in nigeria. Presented at the International Conference of the Centre for the Studies of African Economies, Oxford, United Kingdom. Retrieved from https://editorialexpress.com/cgibin/conference/download.cgi?db_name=CSAE2015\&paper_id=29

Bain, J. (1959). Industrial Organization. New York: John Wiley and Sons Inc.

Baris, P., \& Gergely, N. (2012). Actualisation de l'étude sur la compétitivité du riz de la vallée du fleuve Sénégal sur les marchés régional et national [Rapport définitif]. Paris: AFD.

Bélières, J.-F., \& Touré, E. (1999). Impact de l'ajustement structurel sur l'agriculture irriguée du delta du Sénégal (Thèse de doctorat: agro-économie, Cirad). Retrieved from http://agritrop.cirad.fr/486552/

Bidzakin, J., Fialor, S., \& Yahaya, I. (2018). Production efficiency of smallholder rice farms under contract farming scheme in Ghana. Asian Journal of Agricultural Extension, Economics \& Sociology, 25(1), 112. https://doi.org/10.9734/AJAEES/2018/41057

CARD. (2008). CARD initiative (p. 27). Retrieved from Coalition for African Rice Development website: https://riceforafrica.net/

Cruz, J. F. (1999). Evolution des techniques apres récolte : la transformation artisanale du riz en Afrique sub-Saharienne. Agriculture et Développement, 23, 84-91. 
Demont, M. (2013). Reversing urban bias in African rice markets: A review of 19 National Rice Development Strategies. Global Food Security, 2(3), 172-181. https://doi.org/10.1016/j.gfs.2013.07.001

Demont, M., \& Ndour, M. (2015). Upgrading rice value chains: experimental evidence from 11 African markets. Global Food Security, 5, 70-76. https://doi.org/10.1016/j.gfs.2014.10.001

Demont, M., \& Rizzotto, A. (2012). Policy sequencing and the development of rice value chains in Senegal. Development Policy Review, 30(4), 451-472. https://doi.org/10.1111/j.1467-7679.2012.00584.x

Demont, M., Rutsaert, P., Ndour, M., Verbeke, W., Seck, P. A., \& Tollens, E. (2013). Experimental auctions, collective induction and choice shift: willingness-to-pay for rice quality in Senegal. European Review of Agricultural Economics, 40(2), 261-286. https://doi.org/10.1093/erae/jbs021

Embassy of the United States of America. (2010). Millennium challenge compact between the United States of America acting through the millennium challenge corporation and the Republic of Senegal ( $p$. 70). Retrieved from Embassy of the United States of America website: https://assets.mcc.gov/agreements/compact-senegal.pdf

Fall, A. A. (2006). Impact du crédit sur le revenu des riziculteurs de la Vallée du Fleuve Sénégal (Thèse de doctorat: Economie et gestion du développement agricole, agro-alimentaire et rurale, Ecole Nationale Supérieure d'Agronomie de Montpellier et Université Montpellier I). Retrieved from http://www.bameinfopol.info/IMG/pdf/These_AAFall.pdf

Fofana, I., Goundan, A., \& Magne Domgho, L. (2014). Impact simulation of ECOWAS rice self-sufficiency policy (Discussion Paper No. 01405; p. 32). Retrieved from International Food Policy Research Institute -West and Central Africa Office website: http://reliefweb.int/sites/reliefweb.int/files/resources/ifpridp01405.pdf

François, M., Ngom, M., Diop, A., Lançon, F., \& Ndoye, F. (2014). Etude sur les circuits de distribution et les pistes d'amélioration de leur fonctionnement (Rapport Final No. 4; p. 97). Nogent sur Marne: Groupe de Recherches et d'Echanges Technologiques, Centre de coopération Internationale en Recherche Agronomique pour le Développement, Institut de Recherches et d'Investigations par Sondage, Enda Graf.

Gereffi, Humphrey, \& Sturgeon. (2005). The governance of global value chains. Review of International Political Economy, 12(1), 78-104. https://doi.org/10.1080/09692290500049805

Gereffi, \& Korzeniewicz. (1994). Commodity chains and global capitalism. Westport, Conn: Greenwood Press.

Gergely, N., \& Baris, P. (2009). Etude sur la compétitivité du riz de la Vallée du Fleuve Sénégal sur les marchés nationaux et régionaux (p. 96) [Rapport provisoire]. Retrieved from AFD website: http://www.inter-reseaux.org/IMG/pdf_Etude_Baris_Riz_Senegal_oct2009-2.pdf

Hathie, I., \& Ndiaye, O. (2015). Etat des lieux des impacts des importations de riz sur la commercialisation du riz local (p. 40) [Rapport final]. Retrieved from Initiative Prospective Agricole et Rurale website: http://www.interreseaux.org/IMG/pdf/rapport2_veco_etat_des_lieux_importations_riz_vrsf240215.pdf

Hopkins, T., \& Wallerstein, I. (1986). Commodity chains in the world-economy prior to 1800. Review (Fernand Braudel Center), 10(1), 157-170.

Ijumba, C., Snyder, J., Tschirley, D., \& Reardon, T. (2015). Stages of transformation in food processing and marketing: results of an initial inventory of processed food products in Dar Es Salaam, Arusha, and Mwanza (Food Security Collaborative Policy Briefs No. 210883). Retrieved from Michigan State University, Department of Agricultural, Food, and Resource Economics website: https://ideas.repec.org/p/ags/midcpb/210883.html 
Kaplinsky, R. (2000). Globalisation and unequalisation: what can be learned from value chain analysis? The Journal of Development Studies, 37(2), 117-146. https://doi.org/10.1080/713600071

Le Gal, P.-Y. (1995). Gestion collective des systèmes de culture en situation d'incertitude : cas de l'organisation du travail en double culture dans le delta du fleuve Sénégal (Thèse de doctorat: Sciences Agronomiques). Institut National Agronomique Paris-Grignon, Montpellier.

Lele, U. (1971). Food grain marketing in India: private performance and public policy. Ithaca: Cornell Univ. Press.

MA. (2009). Programme national d'autosuffisance en riz (p. 26) [Rapport intermédiaire]. Retrieved from Ministère de l'Agriculture de la République du Sénégal website: http://www.ipar.sn/IMG/pdf/2009_Prog_Nat_Autosufisance_Riz.pdf

Maertens, M., \& Vande Velde, K. (2017). Contract-farming in staple food chains: the case of rice in Benin. World Development, 95, 73-87. https://doi.org/10.1016/j.worlddev.2017.02.011

Mendez del Villar, P., \& Lançon, F. (2015). West African rice development: Beyond protectionism versus liberalization? Global Food Security, 5, 56-61. https://doi.org/10.1016/j.gfs.2014.11.001

Minten, B., Murshid, K., \& Reardon, T. (2013). Food quality changes and implications: evidence from the rice value chain of Bangladesh. World Development, 42, 100-113. https://doi.org/10.1016/j.worlddev.2012.06.015

Minten, B., Reardon, T., \& Sutradhar, R. (2010). Food prices and modern retail: the case of Delhi. World Development, 38(12), 1775-1787. https://doi.org/10.1016/j.worlddev.2010.04.002

Moustier, P. (2012). Organisation et performance des filières alimentaires dans les pays du sud : le rôle de la proximité. Synthèse des travaux pour l'habilitation à diriger des recherches. Montpellier: UMR MOISA.

Neven, D., \& Reardon, T. (2004). The rise of kenyan supermarkets and the evolution of their horticulture product procurement systems. Development Policy Review, 22(6), 669-699. https://doi.org/10.1111/j.1467-7679.2004.00271.x

Ofuoku, A. U., \& Agbamu, J. U. (2016). Maize contract farming experience in delta state, Nigeria. Journal of Northeast Agricultural University (English Edition), 23(1), 65-73. https://doi.org/10.1016/S10068104(16)30034-4

Osiriz. (2017). Indice and export prices. Observatoire de Statistiques Internationales sur le Riz [Observatoire de Statistiques Internationales sur le Riz (OSIRIZ ${ }^{\text {TM}}$ )]. Retrieved January 17, 2017, from Le portail du riz en Amérique Latine website: http://www.infoarroz.org/portal/fr/content.php?section=14

Ragasa, C., Lambrecht, I., \& Kufoalor, D. S. (2018). Limitations of contract farming as a pro-poor strategy: the case of maize outgrower schemes in Upper West Ghana. World Development, 102, 30-56. https://doi.org/10.1016/j.worlddev.2017.09.008

Reardon, T., Chen, K., Minten, B., \& Adriano, L. (2012). The quiet revolution in staple food value chains: Enter the dragon, the elephant, and the tiger. Retrieved from http://www.adb.org/sites/default/files/pub/2012/quiet-revolution-staple-food-value-chains.pdf

Reardon, T., Chen, K., Minten, B., Adriano, L., Dao, T., Wang, J., \& Gupta, S. (2014). The quiet revolution in Asia's rice value chains. Annals of the New York Academy of Sciences, 1331(1), 106-118. https://doi.org/10.1111/nyas.12391

Reardon, T., Tschirley, D., Minten, B., Haggblade, S., Liverpool-Tasie, S., Dolislager, M., ... Ljumba, C. (2015). Transformation of african agrifood systems in the new era of rapid urbanization and the emergence of a middle class. In O. Badiane \& T. Makombe (Eds.), Beyond a middle income Africa: transforming african economies for sustained growth with rising employment and incomes. Retrieved from http://ebrary.ifpri.org/cdm/ref/collection/p15738coll2/id/130005 
Reardon, T., Tschirley, D., Minten, B., Haggblade, S., Timmer, C., \& Liverpool-Tasie, S. (2013). The emerging "quiet revolution" in african agrifood systems [Brief for "Harnessing innovation for african agriculture and food systems: meeting challenges and designing for the 21 st century"]. Retrieved from Michigan State University website:

http://www.merid.org/ /media/Files/Projects/Africa\%20Ag\%20and\%20Food\%20Systems/Thomas \%20Reardon\%20Paper\%20Quiet\%20Revolution\%20African\%20Agrifood\%20systems.pdf

SAED. (2015a). Productions agricoles dans la Vallée du Fleuve Sénégal: le cas du riz. Retrieved January 24, 2017, from http://www.saed.sn/realisations.html

SAED. (2015b). Protocole d'accord sur la commercialisation du riz sénégalais (p. 5). Dakar: Société d'Aménagement et d'Exploitation du Delta.

Soullier, G. (2013). La gouvernance des chaînes de valeur alimentaires en Afrique : permanence ou changement ? Journal Des Etudiants En Développement International, 2(1), 57-67.

Soullier, G. (2017). Modernization of domestic food chains in developing countries: What effects on smallscale farmers? The rice value chain in Senegal (Thèse de doctorat: sciences économiques, Université de Montpellier). Retrieved from https://tel.archives-ouvertes.fr/tel-01708304/document

Soullier, G., \& Moustier, P. (2018). Impacts of contract farming in domestic grain chains on farmer income and food insecurity. Contrasted evidence from Senegal. Food Policy, 79, 179-198. https://doi.org/10.1016/j.foodpol.2018.07.004

Soullier, G., Moustier, P., Bourgoin, J., \& Ba, A. (2018). Les effets des investissements d'agrobusiness sur les agriculteurs familiaux. Le cas de la vallée du fleuve Sénégal. Économie Rurale, (366), 61-79. https://doi.org/10.4000/economierurale.6262

Swinnen, J., \& Maertens, M. (2007). Globalization, privatization, and vertical coordination in food value chains in developing and transition countries. Agricultural Economics, 37, 89-102. https://doi.org/10.1111/j.1574-0862.2007.00237.x

Tschirley, D., Ayieko, M., Hichaambwa, M., Goeb, J., \& Loescher, W. (2010). Modernizing Africa's fresh produce supply chains without rapid supermarket takeover: towards a definition of research and investment priorities [Working paper]. Retrieved from Michigan State University website: http://ideas.repec.org/p/ags/midiwp/93030.html

USDA. (2013). Senegal, retail food, retails foods sector 2012 (р. 17) [Gain report]. Retrieved from United States Department of Agriculture website:

https://gain.fas.usda.gov/Recent\%20GAIN\%20Publications/Retail\%20Foods_Dakar_Senegal_2-192013.pdf

USDA. (2015). Senegal: grain and feed annual - update West Africa rice annual (p. 18) [Gain report]. Retrieved from United States Department of Agriculture website: https://gain.fas.usda.gov/Recent\%20GAIN\%20Publications/Grain\%20and\%20Feed\%20Annual_Dak ar_Senegal_4-29-2015.pdf

Verhofstadt, E., \& Maertens, M. (2013). Processes of modernization in horticulture food value chains in Rwanda. Outlook on Agriculture, 42(4), 273-283. https://doi.org/10.5367/oa.2013.0145

Waldron, S., Brown, C., \& Longworth, J. (2010). A critique of high-value supply chains as a means of modernising agriculture in China: the case of the beef industry. Food Policy, 35(5), 479-487. https://doi.org/10.1016/j.foodpol.2010.05.005

World Bank. (2008). World development report 2008: Agriculture for development. Retrieved from https://siteresources.worldbank.org/INTWDR2008/Resources/WDR_00_book.pdf 